\title{
AN APPROACH FOR SURVEY OF THE SUSTAINABLE DEVELOPMENT AT REGIONAL LEVEL: CASE OF BULGARIA
}

\author{
Ivaylo IVANOV \\ University of Forestry, Sofia, Bulgaria \\ ihivanov@abv.bg
}

\begin{abstract}
Many national and EU strategies and documents put targets that will lead to a positive change for people and better life. For examples, the EU 2020 strategy assess the progress by indicators focused on employment, investment in research and development, education, energy efficient and risk of poverty. The system for monitoring of sustainable development in Bulgaria includes 56 indicators grouped in ten key areas such as socio-economic development, sustainable consumption and production, social inclusion, demographic changes, public health, sustainable transport, natural resources, global partnership and good governance. But at regional level, these sets of indicators are difficult to apply by many reasons. The aim of research was testing of an approach for survey of the sustainable development of a territorial unit. A complex index for assessment of sustainable development of territorial units was design by set of significant indicators, which evaluate socio-economic conditions for life and development in the territorial unit. The approach and the index were applied for survey of NUTS 3 level regions in Bulgaria, according the EU legislation, by using the last available official data of the National Statistical Institute of Bulgaria. Benefits of the approach using were summarized.
\end{abstract}

\section{Keywords: sustainable development, living conditions, approach, complex index, regions}

\section{Introduction}

Many national and EU strategies and documents put targets that will lead to a positive change for people and better life, which is closely linked with the concept of 'sustainable development'. Economic development, social conditions and quality of environment often go into contradictions. The ranking of counties by sustainable development is interesting for ordinary people and local authorities but not very useful. Much better for them, for their everyday decisions, for better government would be survey of the territorial unit where they live and work. The comparisons of territorial units within the country can improve regional and local policies, the methods of support of regional and local economy, infrastructure projects, different kind of initiatives and etc.

The preliminary analysis showed that the most known and used ways for analysing of sustainable development are inapplicable at regional and local level because of lack or inaccessibility of open data at these levels. The aim of research was testing of an approach for survey of the sustainable development of territorial units.

The research tasks were: studying of the indicator sets using at global and national levels; designing of a complex index for assessment of sustainable development of territorial unit, based on set of significant indicators, which evaluate socio-economic conditions for life and development in the territorial unit; testing of the index with last 
available statistical data. The object of survey was NUTS 3 level regions in Bulgaria, according the EU legislation. The statistical data were obtained by the National Statistical Institute of Bulgaria.

\section{Literature overview}

Sustainable development is 'development that meets the needs of the present without compromising the ability of future generations to meet their own needs. It contains within it two key concepts: the concept of 'needs', in particular, the essential needs of the world's poor, to which overriding priority should be given; and the idea of limitations imposed by the state of technology and social organization on the environment's ability to meet present and future needs' [1]. Since then, many strategies, action plans, studies, researches, surveys and etc. focused on this concept have been published in Bulgaria and abroad. A part of authors have been interested in sustainable development of organisations [13], some - sustainable development of the branches of economy $[12,18,20,22,26]$; other - sustainable development of national economy [29]; fourth - sustainable development of regions $[2,4,9,10,11,16,19]$, fifth - sustainable development in general $[7,14,17]$.

\section{Sustainable development goals and indicators}

\subsection{Global level}

The Sustainable Development Goals (SDGs) have been described and anchored in the United Nation's 2030 Agenda for Sustainable Development. The agenda is an action plan which combines by $5 \mathrm{P}$ - people, planet, prosperity, peace and partnership.

The UN puts 17 sustainable development goals which are related to 169 targets [28]. The logo and the United nation sustainable goals are presented in Figure 1 and Figure 2.

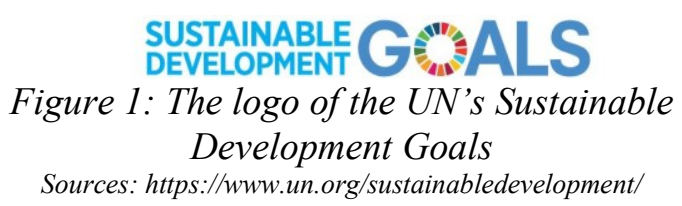

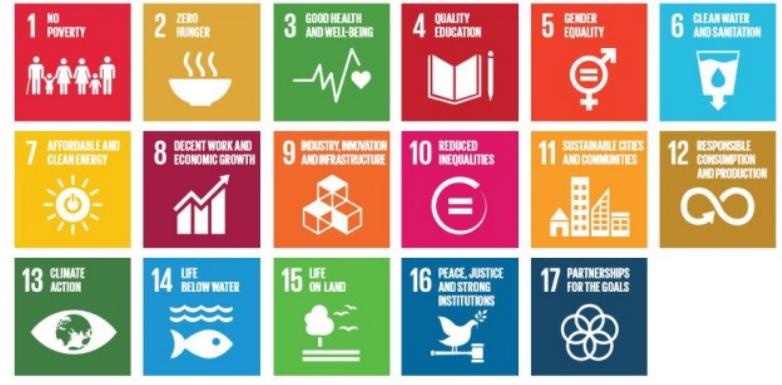

Figure 2: The UN's Sustainable Development Goals

Sources: https://www.un.org/sustainabledevelopment/

\subsection{European Union level}

European Union has been strongly and long linked with the sustainable development concept. The concept has been anchored in many legal document of EU such as the Treaty of European Union, where 'sustainable' was used six times. The Union shall: 'work for the sustainable development of Europe based on balanced economic growth and price stability, a highly competitive social market economy, aiming at full employment and social progress, and a high level of protection and improvement of the quality of the environment'; 'contribute to peace, security, the sustainable development of the Earth'; 'define and pursue common policies and actions, and shall work for a high degree of cooperation in all fields of international relations, in order to: foster the sustainable economic, social and environmental development of developing countries ...; help develop international measures to preserve and improve the quality of the environment and the sustainable management of global natural resources, in order to ensure sustainable development' (Articles 3(3), 3 (5) and 21 (5) of the Treaty of European Union [3]). All EU institutions are involved for achieving the SDGs and they declare that 'the EU is fully committed to be a frontrunner in implementing the 2030 Agenda and the SDGs, together with its Member States, in line with the principle of subsidiarity' [15].

Nowadays, EU uses a set of indicator, which covers all 17 SDGs. The EU Indicator set has been periodically revised. 
For 2019 year, the list includes 99 indicators at NUTS 2 level, which have been divided equally between observed goals. Each goal is assessed by 6 indicators, except goals focused on climate, oceans and partnership [5].

\subsection{National level}

The system for monitoring of sustainable development in Bulgaria includes 56 indicators which have been grouped in ten key areas: socio-economic development, sustainable consumption and production, social inclusion, demographic changes, public health, sustainable transport, natural resources, global partnership and good governance [27].

The indicators for monitoring have been selected by many criteria such as significantly, relevancy, representativeness, availability, easy understandable and etc. [23].

\section{Methodology}

The main steps of methodology for survey of sustainable development at regional level, applied in this research, were selection of significant indicators that were available at regional level (NUTS 3) and calculation of the Regional Sustainable Development Index (RSDI).

The similar of the methodology for assessment of the RCI (the Regional Competitive Index [8]) was applied for calculation of the RSD.

The selection of indicators was by analysing of the data base of the National Statistical Institute [21]. The number of indicators at region level was more than 80 grouped into 21 themes. The most representative, significant and understandable for people indicators were chosen according experts' opinions and assessments (Table 1).

Table 1: Indicator set for sustainable development assessment of regions

\section{A. Economic development}

1. Density of national road network, $\mathrm{km}$ per 100 sq. km

2. Direct foreign investments, thousand BGN per 10000 persons of population

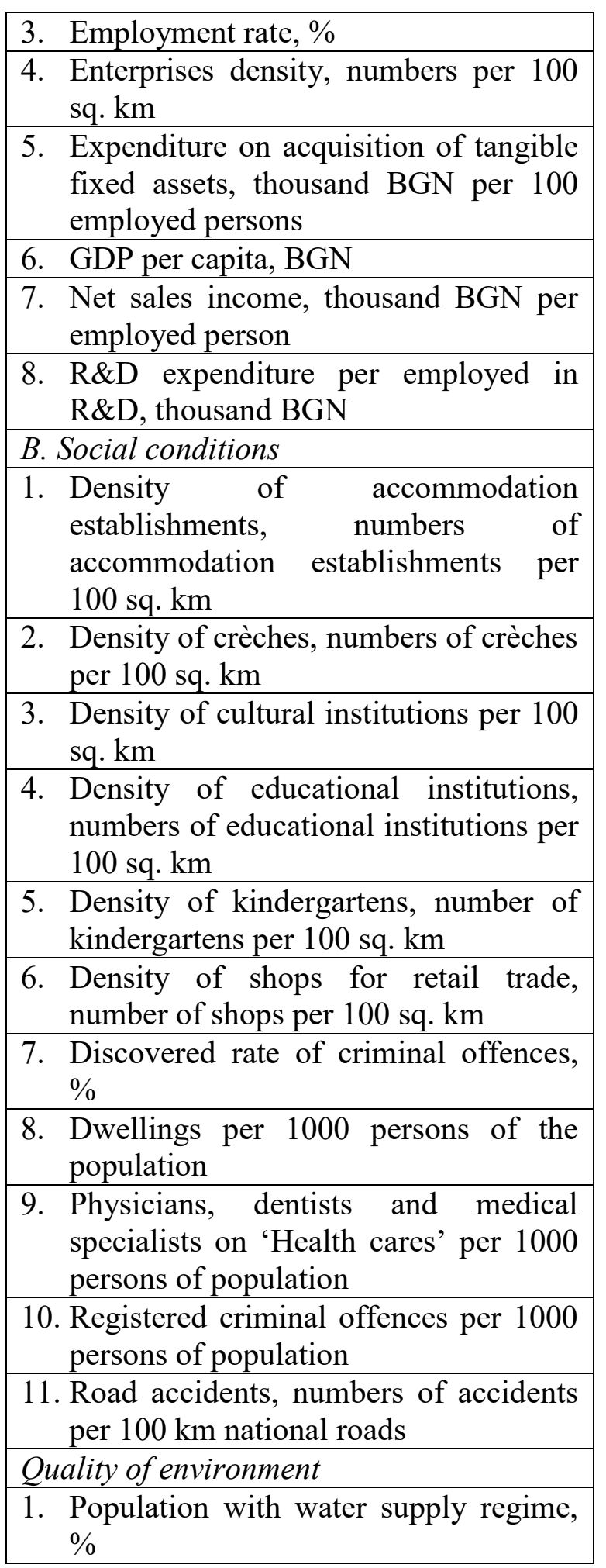

The part of indicators, mainly, which described densities, were result of additional calculations. The indicators have not been equally distributed into the groups because of lack of open data at regional level.

\section{Results and discussions}

The results of the proposed method and the 
indicator set for assessing the sustainable development at regional level in Bulgaria for 2017 are presented in Table 2 .

Table 2: The RSDI Score

\begin{tabular}{|l|c|c|}
\hline Regions & RSDI Score & RSDI Rank \\
\hline Sofia (capital) & 9.245 & 1 \\
\hline Sofia & 15.025 & 2 \\
\hline Stara Zagora & 15.553 & 3 \\
\hline Gabrovo & 15.573 & 4 \\
\hline Burgas & 15.600 & 5 \\
\hline Plovdiv & 15.657 & 6 \\
\hline Varna & 15.658 & 7 \\
\hline Shumen & 16.096 & 8 \\
\hline Ruse & 16.193 & 9 \\
\hline Targovishte & 16.215 & 10 \\
\hline Razgrad & 16.261 & 11 \\
\hline Dobrich & 16.298 & 12 \\
\hline Smolyan & 16.346 & 13 \\
\hline Veliko Tarnovo & 16.372 & 14 \\
\hline Pazardzhik & 16.400 & 15 \\
\hline Yambol & 16.636 & 16 \\
\hline Pernik & 16.657 & 17 \\
\hline Vratsa & 16.720 & 18 \\
\hline Haskovo & 16.873 & 19 \\
\hline Pleven & 17.004 & 20 \\
\hline Blagoevgrad & 17.014 & 21 \\
\hline Silistra & 17.057 & 22 \\
\hline Montana & 17.115 & 23 \\
\hline Kardzhali & 17.119 & 24 \\
\hline Kyustendil & 17.204 & 25 \\
\hline Vidin & 17.283 & 26 \\
\hline Sliven & 17.366 & 27 \\
\hline Lovech & 17.785 & 28 \\
\hline The obtaned & & \\
\hline
\end{tabular}

The obtained results of the RSDI were compared with the RCI and the strong correlation between indexes $\left(\mathrm{R}^{2}=0.959\right)$ was found. This conclusion corresponds with observations at global level where high competitive countries have more sustainable development. The results of the RSDI were checked by correlation with the natural growth and by the migration increase. The moderate negative correlations were found for both indicators. The correlation between the RSDI and the natural growth was -0.443 , and between the RSDI and the migration increase --0.406 . The values show that the decisions in families were affected not only by the economic development in regions but by the social conditions and the quality of environment within.

\section{Conclusions}

The research showed the RSDI was a suitable instrument for study of sustainable development at regional level. The indicator set returned useful results nevertheless that it was a little bit imbalanced. The methodology was easy to use with standard software.

The RSDI can be use for argumentation of regional policies, infrastructure projects, financial decisions and etc.

\section{Acknowledgements}

The present study was initiated and implemented with the support of the National Science Program Young Scientists and Postdoctoral Students. We express our gratitude for the concern for the young researchers, scientists and professors of Bulgaria.

\section{References}

[1] Brundtland, G., Khalid, M., Agnelli, S. et al. Our Common Future ('Brundtland report'). UN. 1987.

[2] Cioancă, L.-M. The Negative Impact Of Tourism In The Area Of The Bârgău Mountains Onto The Local Environment, International Conference Knowledge-based organisation, XXI, 1, pp. 170-178, DOI: https://doi.org/10.1515/kbo-2015-0028, 2015.

[3] Consolidated versions of the Treaty on European Union and the Treaty on the Functioning of the European Union. Official Journal C 326, 26/10/2012. pp. 00010390. [http://data.europa.eu/eli/treaty/teu_2012/oj], 2012.

[4] Devuyst, D. Linking impact assessment and sustainable development at the local level: the introduction of sustainability assessment systems. Sustainable development, 8(2), pp. 67-78, 2000. 
[5] EU SDG Indicator set 2019. Result of the review in preparation of the 2019 edition of the EU SDG monitoring report. European commission. Eurostat. 8.01.2019. [https://ec.europa.eu/eurostat/documents/276524/9479054/2019-0108 EU SDG indicator set 2019 review final report.pdf], 2019.

[7] Hatakeyama, T. Sustainable development indicators: Conceptual frameworks of comparative indicators sets for local administrations in Japan. Sustainable Development, 26(6), pp. 683-690, 2018.

[8] Ivanov, I. Study of regional inequalities: case of Bulgaria, Business, Management and Education. 1(16). pp. 24-36. 2018. https://doi.org/10.3846/bme.2018.2275. 2018.

[9] Ivanov, I. Sustainable Development: regional disparities in Bulgaria, Sofia, Avangard Prima Publishing House (in Bulgarian). 2019.

[10] Ivanova, S., Kamola, L., Kamols, U. Income Inequality and Human Capital as Factors Influencing Economic Development of Region - Case Study of Latvia. Proceedings of the 2016 International Conference on Industrial Engineering and Operations Management, pp. 249-257, Malaysia, Kuala Lumpur, March 8-10, 2016.

[11] Judrupa, I., Senfelde, M. The Competitiveness of Regions in Latvia and Problems of Its Evaluation. International Scientific Conference "Competitiveness in the Conditions of a Global Economy”, pp. 81-88, University of Niš, Serbija, Nis, October 17-18, 2008.

[12] Kolev, K. Social equilibrium between public and private interests as a precondition for sustainable forest management in Austria. Sofia, Knizhen tiger. 2010.

[13] Kuzmanova, M. Sustainable development in the organisations: problems, decisions, perspectives, Journal of Management and Sustainable Development, 1-2(14), pp. 351355 (in Bulgarian), 2006.

[14] Mitchell, G. Problems and fundamentals of sustainable development indicators. Sustainable development, 4(1), pp. 1-11. 1996.

[15] Next steps for a sustainable European future. European action for sustainability. Communication from the Commission to the European parliament, the Council, the European economic and social committee and the Committee of region. COM (2016) 739 final. 22.11.2016. [https://ec.europa.eu/europeaid/sites/devco/files/communicationnext-steps-sustainable-europe-20161122 en.pdf]. 2016.

[16] Nikolova, D., Tsvetkov, A., Ganev, P., Aleksiev, Y., Slavova, Z. Regional Profiles: Indicators for Development, Institute for Market Economy, Sofia. 2016.

[17] Ovidiu Nicolescu, O., Nicolescu, C. New Approach - Quadrangle of Knowledge Based Sustainability, International Conference Knowledge-based organisation, XXIII, 1, pp. 411-417, DOI: https://doi.org/10.1515/kbo-2017-0068. 2017.

[18] Paligorov, I., Yovkov, I. Georgieva, D. Problems of sustainable forest management in Bulgaria within the frameworks of European Union Enlargement, Journal of Management and Sustainable Development, 1-2(1). pp. 57-62 (in Bulgarian), 1999.

[19] Pouhalev, G., Dragozova, E. Green area quality and quantity of biggest cities in Bulgaria in the context of sustainable development, Journal of Management and Sustainable Development, 1-2(14). pp. 312-316 (in Bulgarian). 2006.

[20] Rabontu, C., Vasile, M., Nasta, L. Food Production and Trading Under the Impact of Sustainable Development, International Conference Knowledge-based organisation, XXII, 2, pp. 278-285, DOI: https://doi.org/10.1515/kbo-2016-0048, 2016.

[21] Regions, districts and municipalities in the Republic of Bulgaria, National Statistical Institute. Sofia, [http://nsi.bg/sites/default/files/files/publications/ROO 2017.zip], 2019.

[22] Ruscheva, D., Kovacheva, S. Petkov, A., Neykov, N. International cooperative experience in the context of sustainable development, Journal of Management and Sustainable Development, 3-4(1), pp. 258-261 (in Bulgarian), 2004. 
[23] Selection Criteria for Sustainable Development Indicators for Bulgaria. National Statistical Institute, Sofia, Bulgaria, [http://nsi.bg/sites/default/files/files/data/SDI/Selection\%20criteria-en.pdf], 2019.

[24] Stoenchev, N. Possibilities for application of statistical methods in studying the company's competitiveness, Sofia, Avangard Prima Publishing House (in Bulgarian). 2010.

[25] Stoenchev, N. Quality of life and specialization of the territory by economic activities in Bulgaria (statistical aspects), Sofia, Intel Entrance Publishing House (in Bulgarian), 2016.

[26] Stoenchev, N., Shuleva, N. Vineculture - opportunity for sustainable development of hilly regions in Bulgaria, Journal of Management and Sustainable Development, 34(1), pp. 70-74 (in Bulgarian), 2001.

[27] Sustainable Development. National Statistical Institute, Sofia, Bulgaria, [http://nsi.bg/en/node/7265], 2019.

[28] Transforming our world: the 2030 Agenda for Sustainable Development. United Nation. UN Resolution A/RES/70/1. 25 September 2015. pp. 1-35. [http://www.un.org/ga/search/view doc.asp?symbol=A/RES/70/1\&Lang=E], 2015.

[29] Tsoklinova, M. Economic growth and sustainable development: priorities of new economics, Journal of Management and Sustainable Development, 5(48), pp. 6-12 (in Bulgarian), 2014. 